\title{
The Competency Based Approach to English Language Education and the Walls between the Classroom and the Society in Cameroon: Pulling Down the Walls
}

\author{
Carlous Muluh Nkwetisama \\ Department of English and Literatures of English Expression, Higher Teachers' Training College, University of Maroua, \\ Maroua, Cameroon \\ Email: muluhcarlous@yahoo.com
}

\begin{abstract}
This paper contends that English as a foreign language teaching in the classrooms at all the levels of education is not adapted to the everyday communication needs of the Cameroonian learners and that an English language pedagogy of integration; otherwise known as the outcomes approach or the competency based approach can solve the problem. This approach seeks for linguistic and sociolinguistic competence in the language. In fact, walls seem to exist between the knowledge these learners get in the classrooms and the implementation of the knowledge in the real world society for which that knowledge is destined. Literature in the domain of attitudes and motivation shows that they are affectively predisposed to learn the language. A critical examination of the syllabus revealed that it spells out laudable learning outcomes or expectations and that it has adequate communicative approach recommendations for a post-methods era English language teacher. But recent literature on classroom teaching holds that English language teaching in Cameroon is a matter of teacher talk and chalk and course books; some of which are not adapted to the learners' needs and interests
\end{abstract}

Index Terms - competency, outcomes, affectively predisposed, lathophobic aphasia, cognitive strategies

\section{INTRODUCTION}

It is rather strange to hear that Cameroon is a French-English bilingual country when most of her citizens do not express themselves satisfactorily in both languages. Walls seem to exist between the knowledge they get in the classrooms and the implementation of the knowledge in the real world society for which that knowledge is destined. The focus of this article is on Francophone Cameroonian learners of English. English is 'taught' to them from the nursery level for two (02) years, the primary level for six (06) years, six (06) years at the secondary school level and three (03) years at the university level. In spite of this length of time of learning the language, there is “... much concern and dissatisfaction over the marked deficiency in the level of English used by Cameroonian children at all levels of education" (Odusina and Ayuk (1995, p.32). The contention of this paper is that English language teaching in the classrooms at all the levels of education is not adapted to the everyday communicative needs of the Cameroonian learners and that an English language pedagogy of integration; otherwise known as the outcomes approach or the competency based approach can solve the problem. This is an approach that integrates the knowledge, know-how and attitudes in the solution of real-life problems. This approach seeks for linguistic and sociolinguistic competence in the language.

\section{EXAMination of THE Syllabus SPECIFICATIONS OF THE ENGLiSh LANGUAGE FOR FRANCOPHONE LEARNERS OF CAMEROON}

The syllabus of English for Francophone general secondary schools clearly spells out that English language teaching (ELT) is in a state of constant flux and teachers of English have to be abreast with current trends so that products of the system would not sound outdated in what they do with language. The products of the system would have to use language to cope with the many varying situations and contexts in which they find themselves at all times. Language should be taught in such a way that the learners are provided with study skills and strategies to cope with an everchanging world. In other words, language is taught for effective communication. The syllabus takes into consideration the following pertinent issues:

The socially appropriate and communicative use of language, the linguistic and general structure to include: the social roles that the learners are called upon to play, the language functions and notions that are indispensable for the proper mastery of language, the listening, speaking, reading and writing skills; the grammatical, lexical and pronunciation skills as well as the thinking skills. 
Noteworthy is the fact that this syllabus is skill-based and the various language skills are integrated. The syllabus does not spell out all the themes or the lexicon of the course, but it is through the selection of the various skills and themes that the lexicon is expected to unfold.

The underlying theory of language learning adopted by the syllabus is based on the assumption that language learning is intended for communication between/among speakers in various social contexts. The learners do things and get things done with language in specific situations. In this way, the learners are considered as active participants in the whole learning process. Consequently, they are expected to develop certain skills and strategies of learning how to learn. In other words, the syllabus advocates a learner-centred approach, which focuses and draws from the experience, knowledge and expertise of individual learners. It is activity oriented and lends itself to creativity. The teacher in the whole learning process is considered a facilitator and an organiser. This does not undermine the vital role of the teacher, which is that of creating the learning situation The teacher continues to provide or identify the learning tasks, and organises them in the most interesting and satisfactory manner so that the learners can derive the best from them. The teacher monitors the strengths and weaknesses of the learners in order to ensure that effective learning has taken place. Hence, diagnostic tests and remedial lessons have to be organised from time to time. But, unfortunately most of our teachers seem to ignore this vital role of theirs.

The teacher is supposed to remain the ultimate selector of adequate teaching materials. Authentic communicative materials for realistic language learning are supposed to be selected from every environment. From the syllabus, teachers have to draw up their schemes of work; selecting materials from as many sources as possible.

A further analysis of the syllabus shows that its ultimate aim is to enable learners to: communicate orally and in writing effectively and efficiently in varied situations; develop skills, knowledge of, and about, the language in terms of listening, speaking, reading, writing, grammar and vocabulary.

As for the listening objectives, learners have to be able to develop the ability to listen attentively and respond to stories, news and rhymes; develop the ability to listen and respond to instructions; develop the ability to listen effectively to a variety of text types that will include authentic texts. They equally have to be able to recognise, discriminate and produce accurately the sound system, intonation, stress and rhythm patterns of the language. They have to acquire skills that permit them to identify discourse markers in listening texts that will facilitate understanding i.e. listen for gist, detail, answer questions give instructions, thereby developing the ability to be effective listeners by developing listening skills and appropriate strategies of listening.

The Speaking objectives of the syllabus are as well very laudable as learners are expected to be able to participate as speakers in pair or group activities real or imagined life situations; produce, discriminate and recognise all the sounds of the English language; produce stress and intonation patterns of complex utterance; contribute and respond constructively to discussions, put across their own ideas and justify a point of view. Learners have to read aloud familiar stories, poems and dialogues with appropriate expression; use language to convey information, ideas and emotions effectively in varied situations, contribute to the planning of and participation in a group presentation fluently and finally, use spoken English and written English appropriately.

The specifications of the syllabus concerning reading spells out that Cameroonian learners are supposed to be able to read and respond to all types of writings as well as retrieve information for the purpose of study; demonstrate knowledge of the alphabet in using dictionaries; use picture, context cues and phonic cues in reading. They have to be able to read a range of material with some independence, fluency, accuracy and understanding; read silently and with sustained concentration; read a range of fiction, literary and scientific texts and express preference through talking and writing; identify features of presentation in a text which are used to inform, to regulate or to persuade; read, talk and write about texts, giving personal response and showing understanding of the writer's point of view. Finally the students would be expected to select, retrieve, evaluate and combine information independently and with discrimination from a comprehensive range of materials and develop different reading styles such as skimming, scanning and predicting.

The writing goals that Cameroon Francophone learners are expected to attain by the end of the second cycle of secondary education are among others, to be able to use pictures, symbols or isolated letters, words or phrases to communicate meaning in writing; produce, independently, pieces of writing using complete sentences indicating appropriate punctuation and spelling; structure sequences of real or imagined events coherently and undertake authentic writing tasks such as filling in forms, birth certificates, and curriculum vitae. The students also have to show proof of their ability to write stories that have an opening, a setting, characters, a series of events, conflicts and resolutions which engage the interest of the reader; organise their own writing, revise and redraft them as appropriate; write in a wide variety of forms with a clear sense of purpose and awareness of audience, and demonstrate an increased awareness of the fact that a first draft may be changed, amended and reorganised in a variety of ways. They must show in writing an awareness of what is appropriate and inappropriate language use; demonstrate knowledge of organisational differences between written and spoken English texts; demonstrate in writing knowledge of ways in which language varies between types of texts and be able to sustain a personal style, making an appropriate use of a wide range of grammatical constructions and an extensive vocabulary in distinct paragraphs and maintaining the interest and attention of the reader.

As concerns knowledge about the language, learners should be capable of the following: write letter shapes in response to speech sounds and letter names; read phonetic transcriptions and transcribe words phonetically and produce recognisable spelling of a range of common words. Furthermore, they should be able to spell correctly, in the course of 
their own writing, simple polysyllabic words they use regularly and which observe common patterns; identify and use correctly, regular patterns of vowel sounds and common letter strings; show a growing awareness of word families and their relationship; spell correctly in their writing, words which display other main patterns in English orthography. Finally they would have to recognise words with related meanings, which may have related spellings, even though they sound different; recognise that the spelling of unstressed syllables can always be deduced from the spelling of the stressed syllable in a related word.

The objectives of grammar in the syllabus specify that learners have to be able to use English grammar appropriately to express their thoughts and feelings fluently in correct grammatical utterances and in varied situations and, also to demonstrate a mastery of English grammar in oral and written communication. As for vocabulary, the students should be able to identify or guess the meaning of words from their contexts; use synonyms and antonyms of words in context; develop vocabulary attack skills in order to cope with difficult words. Besides these, they are expected to develop word, phrase and sentence building skills; identify and use false cognates; identify and use homonyms and homophones; and process information in spoken and written texts in order to develop comprehension abilities.

The designers of the syllabus strongly recommend that themes and topics of the course reflect the cosmos and cultural background of the learners and that the course should also provide some openings into the world. Furthermore, supplementary reading is recommended to develop in the learner the reading culture. The materials selected should have to influence the learner to be an active participant in the whole reading process. Thus, they should be placed at the right level in order to enable the learners to read comfortably and with interest. The learner should develop reading skills that would become indispensable for survival in life. Since the underlying principle in supplementary reading is enjoyment, the learners should enjoy reading and should read many books because that will help them to develop many more study skills.

With such a syllabus, it is expected that all Francophone Cameroonians who leave high school should be the real perfect bilinguals; but it is feared that what actually obtains of these learners is the tip of an iceberg of what they are supposed to be.

The poor performances of learners are attested, meanwhile overall recent studies have shown that Cameroonian learners are motivated and have positive attitudes towards the English language. Earlier in 1990, Penn-Tamba carried out a study on the attitudes and motivation of Cameroonians towards the English language and came out with the findings that learners were not very motivated in learning the English language and that they had negative attitudes towards their Anglophone counterparts and native speakers of English. But before then, Tenjoh-Okwen (1987) had posited that Francophone Cameroonian learners were interested in speaking English and that their unsatisfactory performances were to be attributed to factors like poorly trained teachers, large classes and lack of resources. Just like Tenjoh-Okwen, Nkwetisama's (1998) study revealed that these learners were motivated in spite of their poor performances. Akum (1999) endorses those of Tenjoh-Okwen (1987) and Nkwetisama (1998) as she holds that the learners are motivated but that the blackboard, desks and enrolments ranging from sixty to one hundred are what could be found in almost all the classrooms.

More recent concerns about the unsatisfactory performances of Cameroonian learners' attitudes and motivation have been carried out by Owingo (2005), Tchindji Fomo (2007) and Djieuga Tchouatcho (2008). Owingo (2005) sought to find out the attitudes and motivation of Francophone Cameroonian secondary school learners of English. His study demonstrated that the learners were instrumentally motivated and that the problem with students' performance was due to the quality and quantity of teachers posted to teach English in secondary schools. In her investigation into the attitudes and motivation of Francophone students towards English language learning, Tchindji Fomo (2007) found out that the learners were motivated and had positive attitudes towards the English language. Her study also showed that schools lacked resources since classrooms were over-crowded and had no audio-visual materials. Besides resources, she discovered that the teachers were 'harsh' and 'too serious'; and according to her, “...if teachers' methodology was student-centred as they (teachers) claim, students would participate during English lessons and would therefore achieve better performances" Tchindji Fomo (2007, p.68). In another study of Francophone Cameroonian learners' attitudes and motivation towards the English language, Djieuga Tchouatcho's (2008, p.70) subjects held that “... the Anglo-Saxon way of life opens windows to the world." Her study equally revealed that few learners are satisfied with the way their teachers teach.

From the foregoing examination of the literature on the attitudes and motivation of Francophone Cameroonian learners (though with some encroachments on teaching), it is evident that they are affectively predisposed to learn the English language. In spite of this affective readiness, their performances in using the language in examinations and in real-life formal and informal communication situations remain wanting. This state of affaires has also urged researchers such as Ekwogo (2005), Tonzock Folegwe (2006), Ngoulga Ndzana (2006) and Kuatie Tchuimeni (2008) to investigate into the way English language teaching is done in the classrooms.

Ekwogo (2005) undertook a study to find out the attitudes and reactions of teachers towards students' errors. Her results revealed that most teachers view students' errors as a negative aspect of language learning. $70 \%$ of the teachers attributed students' errors to stubbornness, carelessness and negligence. Learners' errors however, are part and parcel of the learning process and are very normal in every human endeavour in real life. Errors are positive indicators that learning is taking place and that are struggling to put into practice what they have learned. This may be the cause of the 
lathophobic aphasia (unwillingness to speak the language for fear of being laughed at) that characterizes many Francophone Cameroonian learners.

Tonzock Folegwe's (2006) investigation into the classroom methodology and its effects on the learners' participation and understanding of English as a foreign language in Yaounde pointed out that most teachers were aware of the existence of many teaching methods and techniques. However, these teachers did not make a systematic use of them. Her findings also revealed that most teachers used the communicative methods but ignored aspects like learners' feelings. Techniques like role-play, group or pair work and games were seldom used in spite of their beneficial effects on language learning. These findings can be interpreted as not bringing the outside world into the classroom so as to facilitate the integration of the classroom into the outside world. In other words, techniques that would enable learners to effectively and confidently use what they learn in the classroom for real time communication in their society.

Students' poor performances have also been attributed to 'obsolete' teaching methods and to the little attention paid by educational authorities on English in science classes at the secondary school level. This, according to Ngoulga Ndzana (2006) has led to lack of interest and motivation to learn the language by these students. Kuatie Tchuimeni (2008) carried out an investigation into the teaching of English in Francophone schools in the West Region of Cameroon. Her results showed that though qualified (i.e. trained), the teachers lacked the appropriate methods adapted to the students' needs and interests. The course books used in secondary technical schools are those meant for secondary general ones. All these point out that upon graduation; most of the learners would not be competent in the English language.

\section{LEARNER INADEQUACIES}

Learners' inadequacies, incompetency and frustrations are often demonstrated in utterances such as "ccest Dieu qui donne l'anglais de quelq'un" (it is God who gives one's English - not the teacher!); "quand on parle, je comprend, mais je ne parvien pas a dire un mot" (I understand when they speak but I cannot utter a word), "l'anglais est trop difficile" (English is too difficult) and "je ne comprend pas votre anglais la" (I do not understand that English of yours). Besides, most learners hardly go beyond routines expressions like "How are you?" and "Fine thanks", and "What is your name?" and "My name(s) is/are ..." This implies that in Cameroon, learners are "taught" grammar, vocabulary and pronunciation but they do not "learn" to use them functionally in English. They are not competent. This situation is compounded by the fact that the learning is geared towards passing the different examinations and not necessarily for real time communication. In fact, English language learning is a matter of the classroom, for the classroom, and not for social interaction. Tchindji Fomo (2007, p. 68) holds that the way the different examination items are set is an impediment to effective language learning. She cites Kouega (1999, p.41) as saying “... students are asked to answer comprehension questions, write essays on philosophical topics and complete complex drills on grammar and lexical structures." This approach may be beneficial to language but it does not help students to master the language in the long run. It explains why many learners are unable to sustain a conversation or write effectively out of the classroom setting. This wall separating the classroom and the society for which the learning is aimed could be demolished through an appropriate application of the competency-based approach to language teaching which targets overall competency in the language use by the learners.

\section{THE COMPETENCY BASED APPROACH}

As earlier stated, the competency based approach is also referred to as the pedagogy of integration or to an outcomes approach. This approach entails the putting together of all the knowledge, know-how and attitudes required for the solution of real life problems or situations. Put simplistically and with reference to language learning, using all the grammar, vocabulary, punctuation and pronunciation to communicate effectively in real time listening, speaking, reading and writing situations. Furthermore, it consists of knowing what to do, where, when and with whom; or, being linguistically, communicatively and sociolinguistically competent with the learned language. CBA as earlier mentioned seeks to bridge the wall between school or the classroom and everyday real life: seeking and giving information by interacting with people in the market, hospital, school, offices etc through listening, reading, writing and speaking; in short communicating: CBA is thus interdisciplinary; for, to effectively solve problems in read life one has to deploy knowledge, know-how and attitudes drawn from several domains of life like history, science and mathematics. CBA therefore integrates theses domains in its approach.

\section{A. Definitions of the Concept}

1. Richards and Rodgers (2001) hold that the competency based approach focuses on the outcomes of learning. It addresses on what the learners are expected to do rather than on what they are expected to learn about. The CBA advocates defining educational goals in terms of precise measurable descriptions of knowledge, skills and behavior $\mathrm{s}$ that students should possess at the end of a course of study.

2. Schneck (1978) views the CBA as an outcome based instruction that is adaptive to the needs of students, teachers and the community. Competencies describe the students ability to apply basic and other skills to situations that are 
commonly encountered in everyday life. Therefore, the competency based approach is based on a set of outcomes that are derived from an analysis of tasks typically required of students in life role situations.

3. To Savage (1993) the competency based model was defined by the U.S. office of Education as a performance based process leading to demonstrated mastery of basic and life skills necessary for the individual to function proficiently in the society. It is therefore a functional approach to education that emphasizes life skills and evaluates mastery of those skills according to actual learner performance.

4. Mrowicki (1986) holds that competencies consist of a description of the essential skills, knowledge, attitudes and behaviours required for effective performance of a real world task or activity. These activities may relate to any domain of life.

\section{B. Components of the Competency Based Approach}

Weddel (2006) outlines the components of competency based education and says that the approach consists of the following:

1. An assessment of the learners' needs

2. The selection of the competencies

3. The target instruction

4. An evaluation of the competency attainment

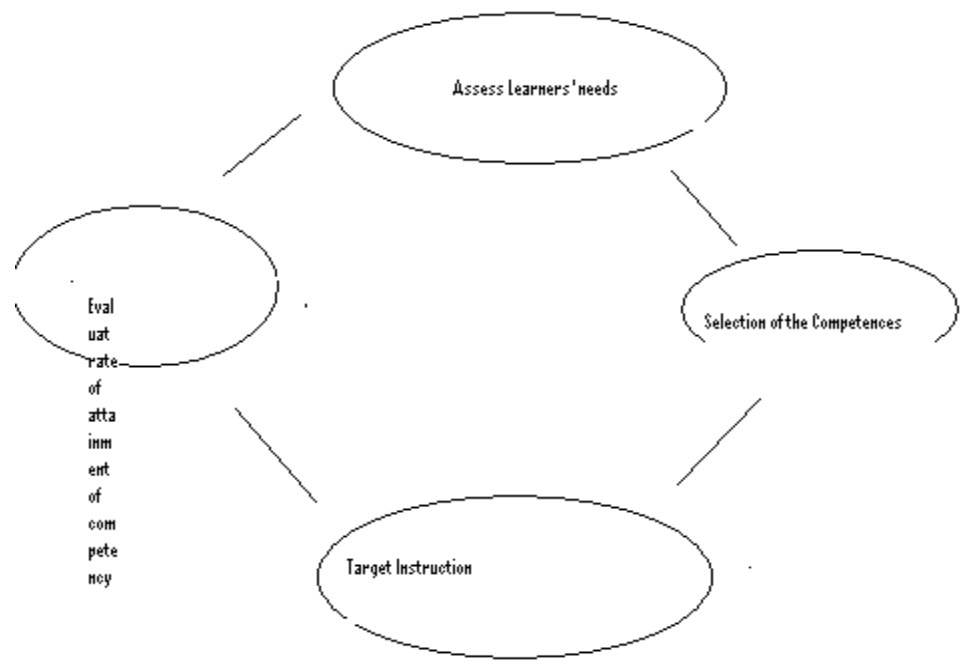

Fig. 1 Components of the Competency based approach

From fig. 1 above it is observed that the four components do not function in isolation. The approach starts with the assessment of needs of the students, moves to the selection of the expected competencies, then to the target instruction from where it moves over to the evaluation of the rate of attainment of the competence, and then back to the assessment of the needs. It is thus a cyclical.

\section{Features of the Competency Based Approach}

The competency based approach is characterizes by the following:

1. The competencies are stated in specific and measurable behavioral terms

2. The contents are based on the learners' goals, i.e. outcomes or competencies

3. The learners continue learning until mastery is demonstrated

4. The approach makes use of an unlimited variety of instructional techniques and group work

5. It centres on what the learner needs to learn, which is the application of basic skills in life skill language context such as listening, speaking, reading or writing

6. The approach makes extensive use of texts, media, and real life materials adapted to targeted competencies

7. It provides learners with immediate feedback on assessment performance

8. The instruction or teaching is paced to the needs of the learners

9. It gets learners to demonstrate mastery of the specific competency statements or objectives

Mapping of some competency objectives or statements 


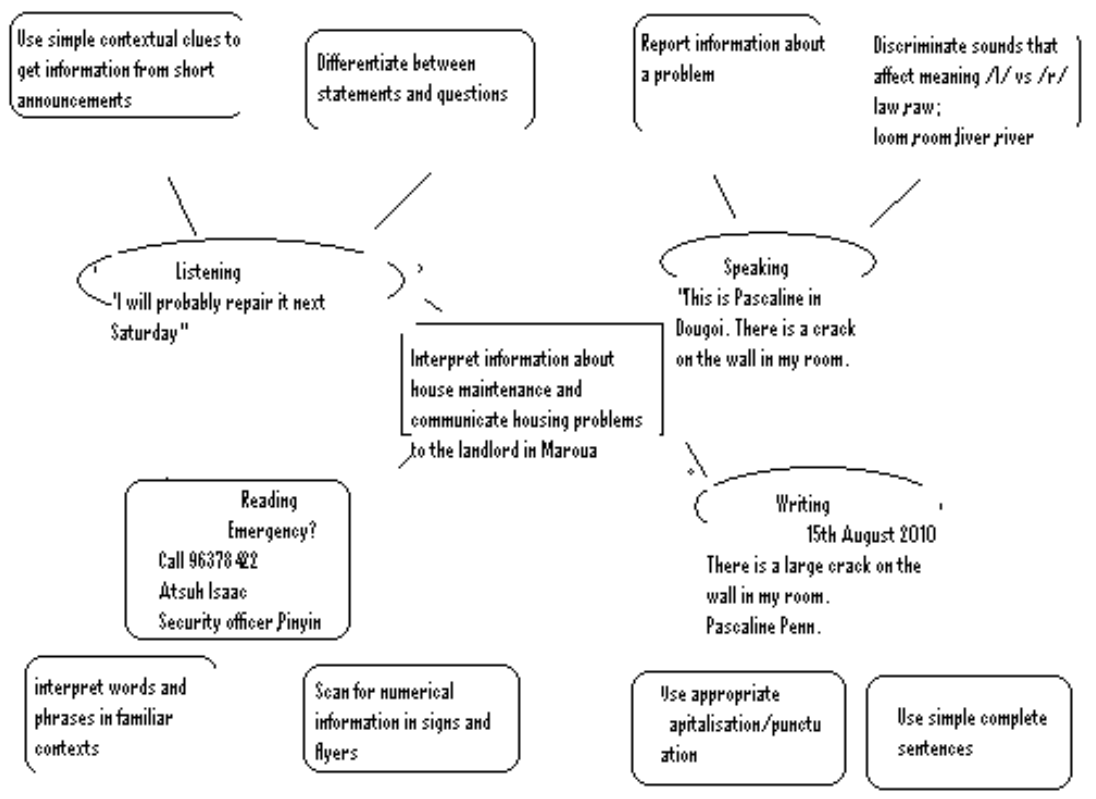

Fig. 2 Mapping of competency statements

In figure 2, the targeted skills are listening, speaking, reading and writing. The specific competency statements make use of tangible and measurable action words like use, differentiate report, interpret and scan.

\section{Integrating Language Segments in the CBA}

Language segments can be broadly categorized into the larger holistic components like functions, topics, situations, notions or into the smaller ones like grammar, vocabulary and pronunciation. Meaningful task based activity or a problem solving complex situation under any of the segments enables learners to be involved more intensively with the language associated with it. Since the competency based model aims principally at the mastery of specific competencies and is learner-participant centred, the techniques used could include the print, audiovisual simulation models. Furthermore, the teaching/learning of pronunciation, vocabulary and grammar is most effective when they are also integrated into activities that use the target item meaningfully for a communicative purpose.

Whether we adopt the larger or smaller segment approach, we do not have to lose sight of the importance of the communicative acts and overall interactive context of language use by over stressing correct grammar and pronunciation.

TABLE

INTEGRATING LANGUAGE SEGMENTS

\begin{tabular}{|c|c|c|c|c|c|}
\hline Situation & Topics & Notions & Functions & Grammar & Vocabulary \\
\hline $\begin{array}{l}\text { Getting to know } \\
\text { some one }\end{array}$ & Tastes hobbies & $\begin{array}{l}\text { Inquiring, } \\
\text { informing } \\
\text { Greeting }\end{array}$ & \multirow{5}{*}{$\begin{array}{l}\text { Offer, request, } \\
\text { promise, advise, } \\
\text { threat, instruct, } \\
\text { apology, remind, } \\
\text { express opinion, } \\
\text { (making requests) }\end{array}$} & $\begin{array}{l}\text { Interrogative forms, } \\
\text { other verbs }\end{array}$ & $\begin{array}{l}\text { Reading, swimming, } \\
\text { past time and leisure } \\
\text { activities }\end{array}$ \\
\hline $\begin{array}{l}\text { Reporting an } \\
\text { incident }\end{array}$ & Road accident & $\begin{array}{l}\text {-Past time } \\
\text {-Narrating } \\
\text {-Describing }\end{array}$ & & -Past tense & $\begin{array}{l}\text {-Drive } \\
\text {-Car etc road scenes }\end{array}$ \\
\hline Shopping & $\begin{array}{l}\text { Food stuff } \\
\text {-Clothes }\end{array}$ & & & $\begin{array}{l}\text { Modals, would, } \\
\text { could, might }\end{array}$ & $\begin{array}{l}\text { Food stuff, clothes, } \\
\text { adjectives of colour, } \\
\text { size, tastes etc }\end{array}$ \\
\hline Planning a trip & Travel, accommodation & $\begin{array}{l}\text {-Future time, } \\
\text {-Predicting } \\
\text {-Suggestion }\end{array}$ & & -Future tense & $\begin{array}{l}\text {-train, plane, bus, } \\
\text { hotel, dormitory inn } \\
\text { etc }\end{array}$ \\
\hline $\begin{array}{l}\text { Asking about or } \\
\text { describing a job } \\
\text { or profession }\end{array}$ & $\begin{array}{l}\text { Jobs/profession } \\
\text { Activities } \\
\text { Equipment }\end{array}$ & $\begin{array}{l}\text { Describing } \\
\text { activities }\end{array}$ & & $\begin{array}{l}\text { Present tense, } \\
\text { Yes/No questions }\end{array}$ & $\begin{array}{l}\text { Teacher, carpenter, } \\
\text { farmer, trader etc } \\
\text { jobs. }\end{array}$ \\
\hline
\end{tabular}

The obviously binary functions are 'offer' usually followed by acceptance or rejection; 'request'; followed by positive or negative response; "instruction”, followed by some expression of comprehension; 'apology', followed by acknowledgement.

All these have to be taken into consideration for competence sake.

The pronunciation column is empty because any aspect of it can be linked to a wide range of activities.

Competence can be applied to language learning and teaching in terms of accuracy and fluency in the language. Mastery of the language means the learner can understand and produce it both accurately (correctly) and fluently (receiving and conveying messages with ease) (Ur: 1999, p. 103). 
The teaching of pronunciation, vocabulary and grammar is accuracy- oriented while focus on the holistic categories of topic, situations, notions, and functions is fluency-oriented. With fluency, emphasis is on producing appropriate language in context and equal importance is attached to form and message. This is then the case with the four skills of listening, speaking, reading and writing where emphasis is lowered on accuracy.

\section{E. CBA Lesson}

A CBA lesson plan calls for;

1) Presentation of the problem-solving situation:

This is the discovery phase and it contains new notions to be discovered by learners. The teacher presents it and gives instructions to learners.

2) Systematisation:

After examining and bringing out relationship between previously learned elements and elements found in the new problem solving situation, learners come out with rules (hypothetical). This is done with the help of the teacher.

3) Application:

Here, the teacher gives tasks where learners apply the new knowledge.

4) Partial Integration Activities:

The teacher presents a new complex situation that will necessitate the exercise of the skill to solve a problem which is similar to the competence/skill the learners used at the beginning of the lesson. Note that this has to be a concrete real life situation

It should be noted also that partial integration activities are not done systematically at the end of every lesson.

TABLE

LESSON FORMAT BASED ON THE COMPETENCY BASED APPROACH

\begin{tabular}{|c|c|c|c|}
\hline Stages & $\begin{array}{l}\text { Intermediary Pedagogic } \\
\text { Objectives }\end{array}$ & Teachers Activities & Learners Activities \\
\hline $\begin{array}{l}\text { Discovery (presentation of } \\
\text { the problem solving } \\
\text { situation) }\end{array}$ & $\begin{array}{l}\text {-To clearly restate the } \\
\text { problem }\end{array}$ & $\begin{array}{l}\text {-Presents the problem solving situation } \\
\text { through statements, drawing, questions, } \\
\text { actions, mimed, etc. } \\
\text {-Ensures that everybody understands } \\
\text { the problem. } \\
\text {-Gives instructions. }\end{array}$ & $\begin{array}{l}\text {-Get acquainted with the } \\
\text { situation by reading or by } \\
\text { listening } \\
\text {-Ask questions if any }\end{array}$ \\
\hline $\begin{array}{l}\mathbf{2} \\
\text { Research (Individually or } \\
\text { in groups seek solution(s) to } \\
\text { problem) } \\
\text { Hypotheses are put forth } \\
\text { and analysed }\end{array}$ & $\begin{array}{l}\text {-To posit and verify } \\
\text { hypotheses }\end{array}$ & $\begin{array}{l}\text {-Recalls the instruction so as to elicit } \\
\text { the emission of hypotheses } \\
\text {-Goes round the groups to help and } \\
\text { encourage learners }\end{array}$ & $\begin{array}{l}\text {-Give hypotheses } \\
\text {-Work individually, and then in } \\
\text { groups, compare their findings. } \\
\text {-Call teachers attention in case } \\
\text { of conflict }\end{array}$ \\
\hline $\begin{array}{l}3 \\
\text { Comparison and } \\
\text { validation of findings or } \\
\text { results }\end{array}$ & $\begin{array}{l}\text {-To present } \\
\text {-To justify the results } \\
\text {-To validate }\end{array}$ & $\begin{array}{l}\text {-Recalls the instructions once more } \\
\text {-Puts away wrong answers and retains } \\
\text { justifiable answers which tie with the } \\
\text { objectives }\end{array}$ & $\begin{array}{l}\text {-Give the answers or solutions } \\
\text {-Justify their answers or } \\
\text { solutions } \\
\text {-Get the final opinion or say of } \\
\text { the teacher }\end{array}$ \\
\hline $\begin{array}{l}\mathbf{4} \\
\text { Institutionalisation and } \\
\text { formulating the new } \\
\text { knowledge (generalisation) }\end{array}$ & $\begin{array}{l}\text {-To formulate the new } \\
\text { knowledge }\end{array}$ & $\begin{array}{l}\text {-Generalizes one case } \\
\text {-Identifies new knowledge } \\
\text {-Introduce new vocabulary (concept) }\end{array}$ & $\begin{array}{l}\text {-Use what they already know } \\
\text { to come up with new } \\
\text { knowledge }\end{array}$ \\
\hline $\begin{array}{l}5 \\
\text { Consolidation (application) }\end{array}$ & -To use the new knowledge & $\begin{array}{l}\text {-Gives exercises (written or oral) to } \\
\text { verify if objectives have been attained }\end{array}$ & $\begin{array}{l}\text {-Get used to new knowledge by } \\
\text { using it accordingly }\end{array}$ \\
\hline $\begin{array}{l}6 \\
\text { Partial integration } \\
\text { activities }\end{array}$ & $\begin{array}{l}\text {-To put together the new } \\
\text { knowledge and know how to } \\
\text { solve a complex problem } \\
\text { situation }\end{array}$ & $\begin{array}{l}\text {-Gives complex problem solving } \\
\text { situations to verify the level of } \\
\text { development of the skill. }\end{array}$ & $\begin{array}{l}\text {-Get acquainted (more } \\
\text { familiar) with the new leanings } \\
\text { and use them in solving real } \\
\text { life problems }\end{array}$ \\
\hline $\begin{array}{l}7 \\
\text { Remediation activities }\end{array}$ & $\begin{array}{l}\text {-To tackle cases of } \\
\text { incomprehension }\end{array}$ & $\begin{array}{l}\text {-Explains over and over that which was } \\
\text { not understood. }\end{array}$ & $\begin{array}{l}\text {-Discover their errors and } \\
\text { rectify them. }\end{array}$ \\
\hline
\end{tabular}

The lesson plan in the table portrays implicit and explicit use of cognitive strategies like noticing or observing, emitting hypotheses and testing them, problem solving and restructuring. This is in opposition to the traditional approach which stressed on structures and functions.

\section{CONCLUSION}

The article sought to examine the competency based education model and then to see how it could be used to remedy the English language learning quagmire among Francophone Cameroonian learners, A critical examination of the syllabus revealed that it spells out laudable learning outcomes or expectations and that it has adequate communicative approach recommendations for a post-methods era English language teacher. The article also examines the affective components of the Cameroonian learners and literature in this domain shows that they are affectively predisposed to learn the language. Recent literature on classroom teaching holds that English language teaching in Cameroon is a matter of teacher talk and chalk and course books; some of which are not adapted to the learners' needs and interests. 
The paper finally examines the competency based education model and recommends that the cognitive learning virtues inherent in the approach could be used to salvage the dismal outcomes of English language teaching in Cameroon.

\section{REFERENCES}

[1] Akum, G. (1999). “An Investigation into some Problems Encountered by Teachers of English as a Second Language (ESL): The Case of Form Four and Five Teachers of some Secondary Schools in Cameroon." Unpublished DIPES II Dissertation. E.N.S: University of Yaounde 1.

[2] Djieuga Tchouatcha, V.R. (2008). "The Attitudes of Some Francophone Secondary School Students Towards English: A Case Study of 'Troisieme' Classes of 'Lycee General Leclerc"” Unpublished M.A. Dissertation. The University of Yaounde I.

[3] Ekwoge, A. M. (2005). "The Attitudes and Reactions of Teachers and Learners towards Errors." Unpublished DIPES II Dissertation. E.N.S: The University of Yaounde I

[4] Kouatie Tchuimeni, L. (2008). "The Teaching of English in Francophone Technical Schools in Cameroon: A Case Study of Two Schools in Bafang." Unpublished M.A. Dissertation. University of Yaounde I.

[5] Mrowicki, L. (1986). "Project Work English Competency Based Curriculum." In Richards, J. and Rodgers, T. (2001). Approaches and Methods in Language Teaching. New York: Cambridge University Press.

[6] Ndehfru, A. M. (1993) "Oral Communication in English; A Focus on Teacher-Student Motivation" Unpublished DIPEN II Diss: ENS: University of Yaounde I.

[7] Ngoulga Ndzana,C.J. (2006). "English Language Teaching in Francophone Science Classes: The Causes of Students' Poor Performance. The Case of Seconde C Classes.” Unpublished DIPES II Dissertation. E.N.S: University of Yaounde I.

[8] Nkwetisama, C. M. (1998). "The Subject-verb ad Pronoun-Antecedent performances of Student: A Study of the Written Productions of 'Premère' and 'Terminale' Students of Lycée de Dschang." Unpublished M.A. Diss: University of Dschang.

[9] Odusina, M. O. \& M. E. Ayuk. (1995). "An Investigation into the Structural Nature of Discourse Generated by Teachers of English as a Second Language”. In Sosongo: The Cameroon Review of the Arts and Social Sciences, 1, 1, pp. 32-48.

[10] Owingo, F.A. (2005). "Attitudes and Motivation of Francophone Cameroonian Secondary School Learners of English." Unpublished DIPES II Dissertation. E.N.S: University of Yaounde I.

[11] Penn Tamba, T. (1990). "Motivation and Attitudes of Francophone Cameroonian Learners of English; A Study in Language Education in a Multilingual Society." Unpublished. Doctorate de Troisième Cycle Diss: University of Yaounde.

[12] Richards, J. \& Rodgers, T. (2001). Approaches and Methods in Language Teaching. New York: Cambridge University Press.

[13] Savage, L. (1993). Literacy through a Competency Based Education Approach. In Approaches to Adult ESL Literacy Instruction. Washington DC: Center for Applied Linguistics.

[14] Schneck, E.A. (1978). “A Guide to Identifying High School Graduation Competencies.” In Richards, J. and Rodgers, T. (2001). Approaches and Methods in Language Teaching. New York: Cambridge University Press.

[15] Tchindji Fomo, I.A. (2007). "Motivation and Attitudes of Francophone Students towards the English Language Learning Process: The Case of CES de Fotouni and Lycee de Bandja." Unpublished M.A. Dissertation. University of Yaounde I.

[16] Tenjoh-Okwen, T. (1987). "Motivation and Attitudes of Francophone Cameroonian Learners of English" in Annals of the Faculty of Letters. Vol. 3, No2, pp. 134-149.

[17] Tonzock Folegwe, A. (2006). "An Investigation into Classroom Methodology and its Effects on the Participation and Understanding of EFL Learners in some Secondary Schools in Yaounde: A Case of 5e Students in Lycee Bilingue d'Etoug-Ebe and ISEIG Nkoldongo." Unpublished DIPES II Dissertation. E.N.S: The University of Yaounde 1.

[18] Ur, P. (2009). "Teaching Grammar: Research, Theory and Practice." in VIEWZ: Vienna English Working Papers. No.18. Vol.3.P.11. Retrieved on $04^{\text {th }}$ March 2010 at 4:22 a.m. at http://anglistik.univie.ac/views/current-

[19] Weddel, K.S. (2006). "Competency Based Education and Content Standards.” Northern Colorado: Northern Colorado Literacy Resource Center.

Carlous Muluh Nkwetisama holds a B.A., a DIPEN II (Diplome de Professeurs de l'Enseignement Normal) an M.A., a D.E.A. (Diplome D'Etudes Approfondies) in English Language studies from the University of Yaounde I in Cameroon where he is a Ph.D candidate pending defending.

Presenttly, he is an English Language Education lecturer and teacher trainer in the Higher Teachers' Training College of the University of Maroua in Cameroon. He has been engaged in teacher training activities for the past fifteen years. His current interests, apart from language pedagogy include Language teaching and global concerns like environmental and peace education, culture and gender issues. 